\title{
Access to Historical Works in a French Library: Documents for Monastic History in the Médiathèque d'Arles
}

DESPITE EVER-INCREASING ELECTRONIC ACCESS to a wide variety of information resources, academic librarians need to remember that a significant number of historical documents are not available in digital form; nor have the catalogs or bibliographies containing these documents been digitized. While it is true that many libraries in Europe, as well as the United States, now make their general library catalogs available on the Internet, frequently there existed manuscripts and documents that never were included in the original card catalog that served as the basis for the online catalog. Thus, the historical scholar must depend on reference sources, such as book catalogs of manuscripts, many of which were begun in the 19th century and have added supplemental volumes over the years.

The author's research into the history of the monastery of St. Caesarius, an important medieval women's monastery in Arles, France, raised the question of how much can be discovered in reference sources, compared to what might additionally be discovered by paying a visit to the library itself. This paper will focus on the types of materials for monastic history that can be found by visiting one of the smaller municipal libraries of France, and what kind of bibliographic access is now provided, either through reference sources or by the library itself to these manuscripts and books, including how well the descriptions represent for the scholar the contents of the works themselves. Specific details on some of the resources available at the Médiathèque d'Arles are included as examples of the types of materials that can be found, as well as for the information of scholars interested in the monastic history of Arles and Provence.

\footnotetext{
The author gratefully acknowledges the support of the ACRL Coutts-Nijhoff Western European Specialist Study Grant for the research conducted in Arles. Thanks also to Professors M. Winslow Lundy and Thea Lindquist for their helpful comments on drafts of this article, and to Mlle. Fabienne Martin, archivist at the Médiathèque d'Arles, for her assistance with the sources.
} 
With the exception of the French Bibliothèque Nationale and the French national archives, sources for information about the resources in collections in France can be difficult to find, even though some reference sources do exist. Erwin K. Welsch's Archives and Libraries in France, with 1991 Supplement, is now dated, and it includes only brief descriptions for the archives of the various regional départements, but none for local or city archives. ${ }^{1}$ The International Council on Archives published a list of archives in France that was comprehensive, but only through the mid-1980s when it was published. ${ }^{2}$ There is also a bibliography of inventories of medieval manuscripts from 1987 that has several useful indexes to places, names, and types of institutions that can be a helpful starting point. ${ }^{3}$ The principal resource for manuscripts in France, outside of Paris, however, is the Catalogue général des manuscrits des bibliothèques publiques de France. Départements. ${ }^{4}$

Basically a census of manuscripts in the libraries outside of Paris, the Catalogue général has been compiled since 1886 , and periodic updates continue to be published. The manuscripts are listed under each library in the order of their accession numbers, so only if a collection was cataloged consecutively does one find any kind of grouping by type or topic. The listings for a particular library are found in more than one nonconsecutive volume, as supplements were added to the original volumes. So, for example, listings for Arles can be found in volumes 20 (1893), 40 (1902), and 49 (1951). Although the Bibliothèque Nationale has discussed digitizing this important reference source, such an undertaking has not yet begun. ${ }^{5}$

Many archives and libraries in France now have Web sites that make it much easier than in the past to discover the days and hours the facility is open to researchers, as well as any special requirements for accessing the resources. Most of the regional and local collections are open to anyone upon registration with a valid ID, such as a passport. However, a major difficulty in discovering these Web sites is that one has to know its official name to use when searching. For example, the département for the regional archives of Provence in Marseilles is actually Bouches-du-Rhône. Many of the bibliothèques municipales in French cities are now known as médiathèques. Fortunately, there is often a link from a particular city's Web site (for example, the

1. Erwin K. Welsch, Archives and Libraries in France, with 1991 supplement (New York: Council for European Studies, 1991).

2. International Council on Archives, "International directory of archives: France," Archivum 33 (1988): 153-98.

3. A.-M. Genevois, F.-F. Genest, A. Chalandon, Bibliothèques des manuscrits médiévaux en France. Relevé des inventaires du VIIIe au XVIIIe siècle (Paris: Editions du Centre National de la Recherche Scientifique, 1987).

4. Catalogue général des manuscrits des bibliothèques publiques de France. Departements (Paris: Librairie Plon, 1886-).

5. Personal communication of Fabienne Martin, curator of the fonds patrimoniaux at the Médiathèque d'Arles. 
city of Arles) to the library's Web site, which can be a useful strategy to employ if a direct link to a library or archive cannot be found.

The Médiathèque d'Arles, formerly the Bibliothèque Municipale of Arles, is an example of libraries founded in the early 19th century in many of the cities of France, shortly after the Revolution. Although it is used today as a bustling public library for the citizens of Arles, at its heart are the fonds patrimoniaux, collections confiscated mostly from religious and monastic institutions following the French Revolution. The process of confiscation is fairly well documented, but many of the manuscripts and books were stored in warehouses or other expropriated buildings, in no particular order and without any listing of the contents. ${ }^{6}$ Many others were undoubtedly lost or destroyed. It is difficult to know, therefore, what one might expect to find in examining these collections.

The Bibliothèque Municipale of Arles was founded in 1821 with 4,500 confiscated works. The collection was augmented soon after with over one hundred manuscripts and a number of books from the collection of a local priest, Laurent Bonnemant. ${ }^{7}$ Of particular interest to the historian is that Père Bonnemant spent a considerable amount of time in the 1770s and 1780s copying out documents from the archives of the city's monasteries, especially those of St. Caesarius, a woman's monastery founded in the early sixth century by St. Caesarius himself. Since the archives themselves disappeared during the Revolution, these transcriptions provide invaluable access to documentation otherwise lost to history.

The entries for each manuscript in the Catalogue général list the manuscript number assigned by the library and either the actual title on the document itself or, for items without a title, a constructed title indicating the contents. Many of the documents at the Médiathèque d'Arles consist of manuscript items that were later bound together in one or more volumes; in these cases, a listing of the titles of the individual manuscripts and number of pages they comprise is also included. The material of the document, whether paper or parchment, as well as the date (or at least a century), follows. These listings allow the scholar to identify what manuscripts might be useful to look at in advance of traveling to the library. However, the titles can be fairly brief and cryptic, thereby obscuring a document that turns out to be more significant than the listing would initially lead one to believe. For example, one of the items, dated to the 17 th and 18th centuries, is identified as a "miscellaneous collection" and has the vague title "Relations of several curious

6. Dominique Varry, "Les confiscations révolutionnaires" in Histoire des bibliothèques françaises v.3. Les bibliothèques de la Révolution et du XIXe siècle 1789-1914 (Paris: Promodis, 1991): 9-27.

7. According to the Web site for the library at www.ville-arles.fr (click on Culture, then Médiathèque) (accessed Sept. 2, 2008). 
events that happened at Arles in Provence." Within this collection, one of the manuscripts is titled "Recital of what happened at the Monastery of St. Césaire of Arles the 10 January 1519 and the following days." ${ }^{8}$ This is still not very helpful, although it is now apparent that the events being described are from the 16th, not the 17 th or 18 th centuries.

The document itself actually contains a fascinating narration of a conflict that occurred when an abbess died. Her successor was elected by the community as usual, but the king chose to appoint someone else from outside the community, sending one of his councilors to enforce her installation as abbess. Several armed men, including (presumably) the brother or father of the elected woman, entered the monastery to defend it and were arrested. The councilor of the king and his supporters ended up breaking down the door to the abbess' room with a hatchet, and the elected woman was forced to leave the monastery and return to her family's house, thus clearing the way for the installation of the king's appointee. There then follows an inventory of the important and valuable relics of the monastery that the Commissaire of the Parlement, who had been sent to adjudicate the issue, ordered compiled to be certain that the elected woman had not taken any of the relics with her. So not only does this document contain an interesting incident in the history of the monastery and its struggle with the king over the appointment of an abbess, but it also includes an inventory of the mostly silver relics and reliquaries, including some of St. Caesarius himself, for which there is no hint in the listing for this manuscript in the Catalogue général.

Access to printed books in the fonds patrimoniaux is available through the library's public online catalog. ${ }^{9}$ Author, title, and subjects may be searched; but, although there is a line for searching by the original collection that contained the item, this does not appear to work, either alone or in combination with another search term. Once a record has been found, however, the name of the collection is hotlinked; clicking on the link then brings up all the other titles from that collection. In this way one can discover that there are 194 volumes contained in the Laurent Bonnemant collection and 375 in the Bibliothèque d'Arles collection. Within the list of the titles in the latter collection, some records link to a second collection, from which the provenance can be determined.

That link also provides a list of only those titles in the smaller collection. For example, collections for the Capuchins, College of Jesuits, Library of the Preachers (Dominicans), Abbey of Montmajour and Recollets were found. Although the

8. Bibliothèque Municipale d'Arles, Ms. 424. Document titles are the author's translations from the French.

9. Web site www.ville-arles.fr (click on Culture, Médiathèque, then Recherche documentaire). 
number of volumes in these collections is small, either because the monastic libraries were destroyed or because there are volumes without any indication of previous ownership, the lists still offer an opportunity to gain interesting insights into the intellectual milieu of the different monasteries. Consider, for example, that the Library of the Preachers (Dominicans) included among the forty-two titles listed works of Erasmus, Aulius Gellius, and Thomas Aquinas. The Abbey of Montmajour (Benedictine) contained works by Aristotle, Rousseau, and Linnaeus, as well as a Hebrew grammar. Other libraries had only the more traditional works of Church Fathers and monastic spirituality. So while the online catalog does provide interesting access to books of the fonds patrimoniaux, for the history of the monasteries of Arles themselves, the manuscripts, the most important sources, are not listed in the online catalog.

There are municipal libraries in France that contain much larger collections of monastic books and manuscripts. For example, Troyes has more than 1,400 manuscripts from Bernard's monastery of Clairvaux, an important house in the history of monasticism in Europe.$^{10}$ But smaller collections, such as the one in Arles, also have much to offer the historian of monasticism and monasteries. The city of Arles has a venerable Roman past and early Christian connections. Christians of the fifth century believed that their community was founded by St. Trophime, disciple of St. Paul, who was sent from Rome to convert Gaul around 40 C.E. Although this fact has not been proven, it is known that a Christian community that was organized around a bishop Marcianus existed around $254 .{ }^{11}$

In the early sixth century, St. Caesarius was bishop of the city, and he wrote a monastic rule especially for women in the monastery he founded for his sister, Caesaria the Elder. ${ }^{12}$ This rule was widely admired and adopted by other women's monasteries in Merovingian Gaul; and, although the Benedictine rule superseded it under the Carolingians, the monastery of St. Caesarius, as it later came to be known, survived until the French Revolution in its original location within the high point of the Roman wall around Arles. Evidence of the importance of this monastery during the Middle Ages can be found among the manuscripts of the Médiathèque d'Arles, where there are copies or translations, and in some cases the original documents, of the abbesses' correspondence with the popes, kings, and Holy Roman Emperors of their times. There are also manuscripts such as the one quoted above that give insights into important incidents that occurred within the monastery, as well as land records that note it as owner of parcels of land, fish-

10. Anne Bondéelle, "Tresor des moines. Les Chartreux, les Cisterciens et leurs livres" in Histoire des bibliothèques françaises v. 1. Les bibliothèques médiévales: du VIe siècle á 1530. (Paris: Promodis, 1988): 66.

11. Michel Baudat, Arles, ville sainte: les églises célébres et oublieés (Arles: Actes Sud, 2002): 9.

12. The edition and translation by M.C. McCarthy, The Rule of Nuns for Women of Saint Caesarius of Arles, (Washington, D.C.: Catholic University Press, 1960) is still the standard source. 
ing rights, and the like in the surrounding countryside. Each of these documents affords a more detailed picture of the history of an important monastery of the Middle Ages.

Although the monastery of St. Caesarius is the oldest in Arles, many others were also established in the town, particularly after the founding of a number of new orders during the 12th and 13th centuries. For men, there were Trinitarians, Great Augustinians, Dominicans, Recolets, Discalced Carmelites, Reformed Augustinians, Friars minor (also known as Cordeliers), Minimes, Order of Malta, and the Benedictine monastery of Montmajour a couple of miles out in the countryside. Orders for women included the Benedictines of St. Cesarius, Carmelites, Visitandines, Religious of St. Paul, and Ursulines. ${ }^{13}$ By the first half of the 15 th century, in a city that had a population of only about five or six thousand, there were seventeen churches and chapels in Arles, and ten convents or religious houses. ${ }^{14}$

During the 18th century, however, there was increasing dissatisfaction in France with the power and wealth of monasteries. Many convents and monasteries saw their number of members dwindle to a handful, or were suppressed or combined with other houses. ${ }^{15}$ Such sentiments burst forth with some ferocity during the Revolution. The National Constituent Assembly's decree of 2.11.1789 claimed all property of religious communities for the state, while the decree of 14.11.1789 ordered the occupants of religious houses to deliver a report on the state of their libraries, together with their catalogs, to the nearest municipal authority or royal record office. ${ }^{16}$

Religious orders were, however, reluctant to comply with the decrees, and many of the declarations were false. As a result, in 1790, responsibility for reporting on the libraries was transferred to local authorities, who were also mandated to preserve the possessions of former religious houses, put seals on the buildings, and have inventories made and sent to the Comité d'Instruction Publique in Paris. Because of delays in executing the orders, many books and manuscripts disappeared from the collections, often winding up in the hands of the unscrupulous. ${ }^{17}$ Even once established, depots littéraires were often kept in unsuitable buildings with poor ventilation, dampness, and vermin, and no heat in winter for those working on the inven-

13. "Recherches pour servir á l'histoire de l'eglise d'Arles par le Sr. Pierre Veran,” 1800, Bibl. Mun. Arles M794, t. 3, 173.

14. Louis Stouff, Arles au moyen age ( Marseilles: La Thune, 2000): 199, 211-12.

15. See Mita Choudhury, Convents and Nuns in Eighteenth-Century French Politics and Culture (Ithaca: Cornell University Press, 2004) for a discussion of this phenomenon.

16. Graham Keith Barnett, The History of Public Libraries in France from the Revolution to 1939 (Thesis, Library Association, 1973. Reprint, UMI, 1988): 40, 42.

17. Ibid., $42-43$. 
tory. ${ }^{18}$ Given these facts, it is amazing that any books and manuscripts survived at all. In addition, progress establishing bibliotheques municipales from the books in the depots was also slow and uneven, often depending on the interest and energies of a learned, or former religious, person in the area. Yet by 1830 there were nearly two hundred municipal libraries in France. ${ }^{19}$

The municipal library in Arles seems to have been one of the more fortunate of these libraries, having moved into an annex of the city hall in 1822 with 4,500 confiscated books. By 1821 it had also acquired a rich collection of books belonging to a former president of the parliament of Provence,

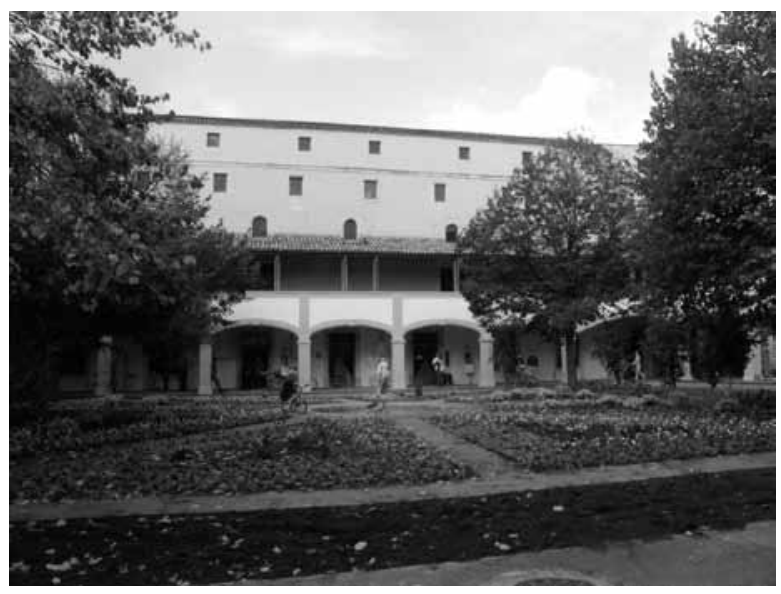

Illustration 1. Historic exterior of the Médiathèque d'Arles on the courtyard Espace Van Gogh.

and in 1834 it received

more than one hundred manuscripts, as well as books of the former priest of the chapter of the cathedral, abbé Laurent Bonnement. Because of its history, and especially its Roman remains, Arles has been fortunate in having a number of erudite native sons who took an interest in collecting sources and documenting the city's past and whose families often donated their libraries to the municipal library following their deaths. Eventually the library outgrew its space and, in 1923, was moved to the old archbishop's residence, where it remained until 1989. ${ }^{20}$

In that year it moved to the newly renovated former hospital at Espace Van Gogh, where the fonds patrimoniaux now enjoy a storage area with environmental controls for preservation and a spacious reading room where scholars may consult the works. Following a trend among French public libraries in the 1980s, its name was changed to the Médiathèque d'Arles. Located on other floors are collections and reading areas more typical of a public library. The old and historical sit side by side with those that are new and modern, and anyone may consult any of the collections.

20. Fabienne Martin and Antoine Lemaire, "Arles: Médiathèque municipale" in Patrimoîne des bibliothèques de France. Un guide des regions, v.6. Provence-Alpes-Côte d'Azur, Corse, Martinique (Paris: Payot, 1995): 44-47. 


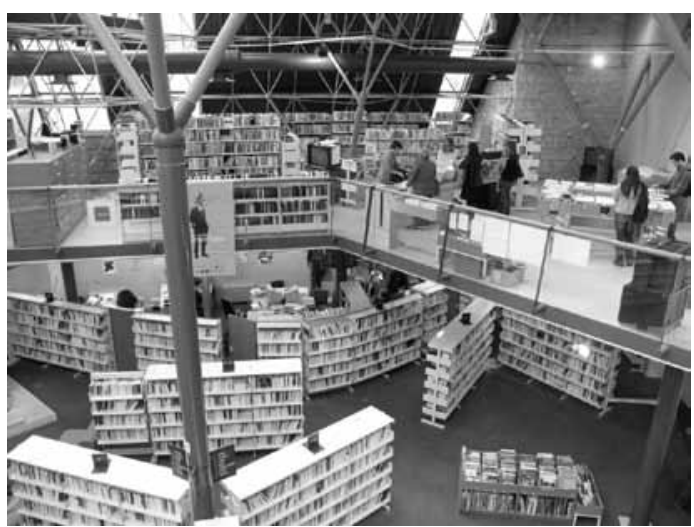

Illustration 2. Remodeled interior of the Médiathèque d'Arles; note the old stone wall in upper right.
A major advantage for the researcher in working at a smaller library such as this one is that only a few people use the historical collections on any given day. One need merely fill out a registration card and then request the volumes of interest. Wait times for receiving materials are short, and a document can be held in the librarian's office if it is going to be used over a

number of days. But one disadvantage is that the library is not open on Sunday and Monday, and on other days often does not open until 12:30 or 1:00 p.m. This must be taken into account when planning research time.

The manuscripts in the Médiathèque d'Arles of interest for local monastic history fall into a number of categories. Monastic rules include the rule of the Poor Sisters of St. Clare from the convent in Nîmes, 1527 (M63), the rule and constitutions of the religious of Notre Dame de Miséricorde, 1649 (M64), and the statutes and constitution based on a rule of St. Augustine for the religious of Notre Dame du Refuge, 18th century (M66). ${ }^{21}$ In M168 there is a transcription from the late 18th century of the rule that St. Caesarius wrote for the monastery of women he founded in the sixth century, in both Latin and French (pp. 53-84) with notes on the rule by Melchior Fabre, (pp.85-168), a former provincial of the order of Minimes who also wrote a chronology of the Abbey of St. Caesarius in the late 17th century (see below).

Another category comprises liturgical works, prayers, and sermons. Included are a book of prayers and precepts (M436) purported to have come from the Abbey of St. Caesarius, according to a note in the manuscript dated 1860. The 238-page book contains precepts and maxims, a meditation on the Psalms, observations of a noblewoman on the Easter sermons of the priest in 1676, and rules of conduct. A three-volume antiphonary used by the White Penitents of Arles, 18th century (M474-476), and a book of daily exercises, prayers, and recommendations for the Reformed Religious, 18th century (M970) are also found here.

21. Numbers in parentheses, e.g. (M63), are the manuscript numbers assigned by the library and noted in the lists of the Catalogue général. Descriptions are the author's translations from the French. 
Documents from or about specific monasteries or convents form another category. A two-volume compilation (M159-160) includes ordinances of the archbishop on the suppression of the Oratorians and documents on the religious of St. Clare and the Ursulines from the 17 th century, as well as a Latin document of 1406 titled "De reclusis puellis." Annals of the convent of Minimes from 1591 to 1705 (compiled by Fabre, M166) contain the bull of Pope Paul V confirming the foundation in 1619 on parchment with a lead seal. The chronology of the Abbey of St. Caesarius by Fabre, noted above (M168), lists all the abbesses since the refounding of the monastery in the eighth century, with

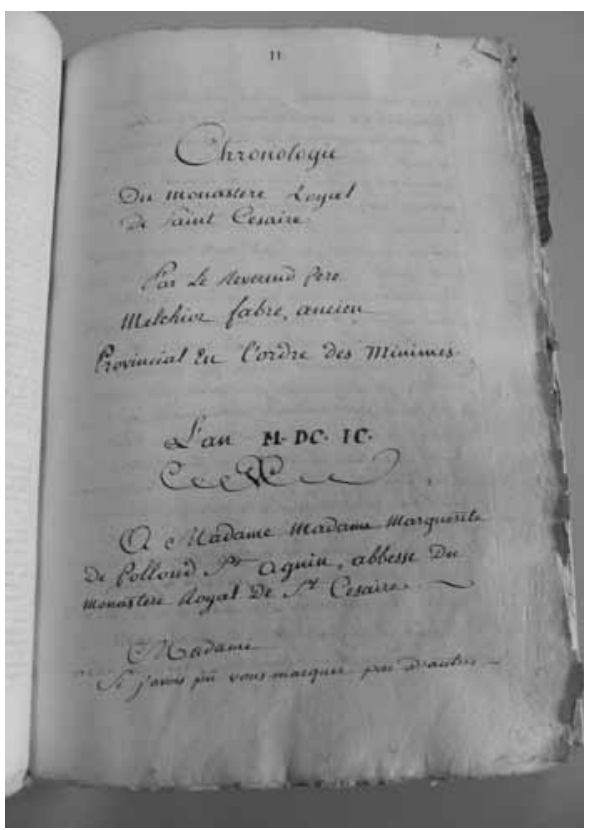

Illustration 3. History of the women's monastery of St. Caesarius, written in 1690. one or more pages for each describing the significant events of their abbacy.

The bound volume also includes copies of the bulls and charters in Latin made by Abbé Bonnemant in the late 18th century, presumably from the now lost originals at the Abbey, as well as one original parchment and one early printed document bound in.

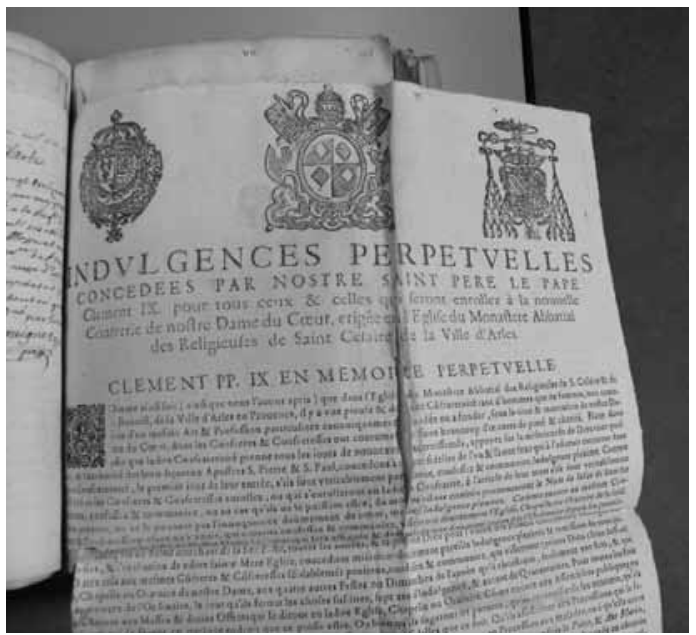

Illustration 4. Printed document bound into the 1690 history.
There is a manuscript (M170) on the history of the monasteries of the Misericordia in Arles, including a letter from Queen Anne to the archbishop about its founding in 1664, a brief by Pope Clement IX confirming the election of the superior-general in 1668, and the order of suppression in 1751. There is a two-volume archive of the Convent of the Penitents established in 1665 to care for penitents, mostly 


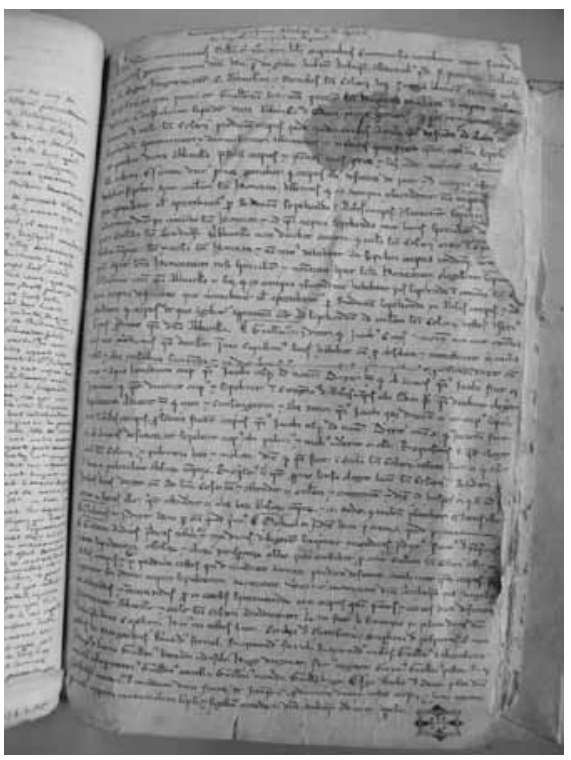

Illustration 5. Parchment document bound into the 1690 history. sent there by the courts, which continued until 1789. A group of manuscripts (M470-476) about, or belonging to, the White Penitents at the Convent of St. Augustine includes the names of rectors from the convent's founding in 1532, names of the penitents for various periods into the 18 th century, as well as a three-volume antiphonary that was used.

Also included in this category of works about particular monasteries and convents are two volumes that contain information about all the institutions. The first is tome 2 (M793) of a four-volume history of the church in Arles by Pierre Véran, dated 1800 . It covers all religious foundations for men and women, as well as the establishment of hospitals, schools, and cemeteries. The second work is tome 6 of a nine-volume collection of documents, by the same Pierre Véran, that includes ten parchment documents from the 12th and 13th centuries among the 112 pieces in the volume issued by a number of the most important monastic orders in Arles.

Works on the history of the church in Arles may also be of interest to the monastic historian for the context they provide for the more directly monastic documents. In addition to the two multivolume sets noted above (M792-795 and M797-805), there are also a number of shorter manuscripts. One of these (M110) describes the suppression of the monastery of Montmajour and enumerates the goods and revenues of the abbey. Another is a two-volume compilation by Laurent Bonnemant on the history of the church in Arles from its supposed founding by St. Trophime in the first century up to archbishop Pierre Isnard in 1190. Manuscript M151 has a map of the diocese of Arles with parish names in red. Manuscript M468 is a collection of documents from the 15th century copied and collated by the royal notary in the 18th century. M469 is a history of the archbishops of Arles by Laurent Bonnemant, and M482 is a collection of mandates and ordinances from the bishops and vicars general.

Other categories of documents of interest include inventories, directories, letters, vitae, and wills. In addition to the inventory serendipitously discovered in the rela- 
tion of the incident described at the beginning of this paper (M424), there is also an inventory of the library of the abbey at Montmajour (M528). A 1775 document on the abbey of St. Caesarius, which contains a map of the buildings, is especially useful since almost all of the structures belonging to that monastery were torn down during the Revolution. Directories include those of the sisters of Notre Dame de Misèricorde from the 17th century, and a collection of documents listing the names of women religious of several monasteries and convents from the 17th and early 18 th centuries. Of potential interest for comparison to these lists of names is a compilation of the noble families of Arles, again by Laurent Bonnemant (M299300). From examining these, one could see which monasteries were favored by the nobility for their children and which had no noble names at all in their lists.

Letters are represented by M98, a collection to a sister of the Carmelite monastery in Arles. Vitae are found in M296, which, in addition to the familiar stories of the sixth-century lives of St. Caesarius, St. Hilarius, and St. Rusticula, also includes the life of an Ursuline sister of Arles from a much later time. A collection of wills is found in M298 that date from 1131 to 1780, many of which are the originals on parchment or paper. Another singular document of interest is an examination of a candidate to the novitiate of the convent of the Visitation.

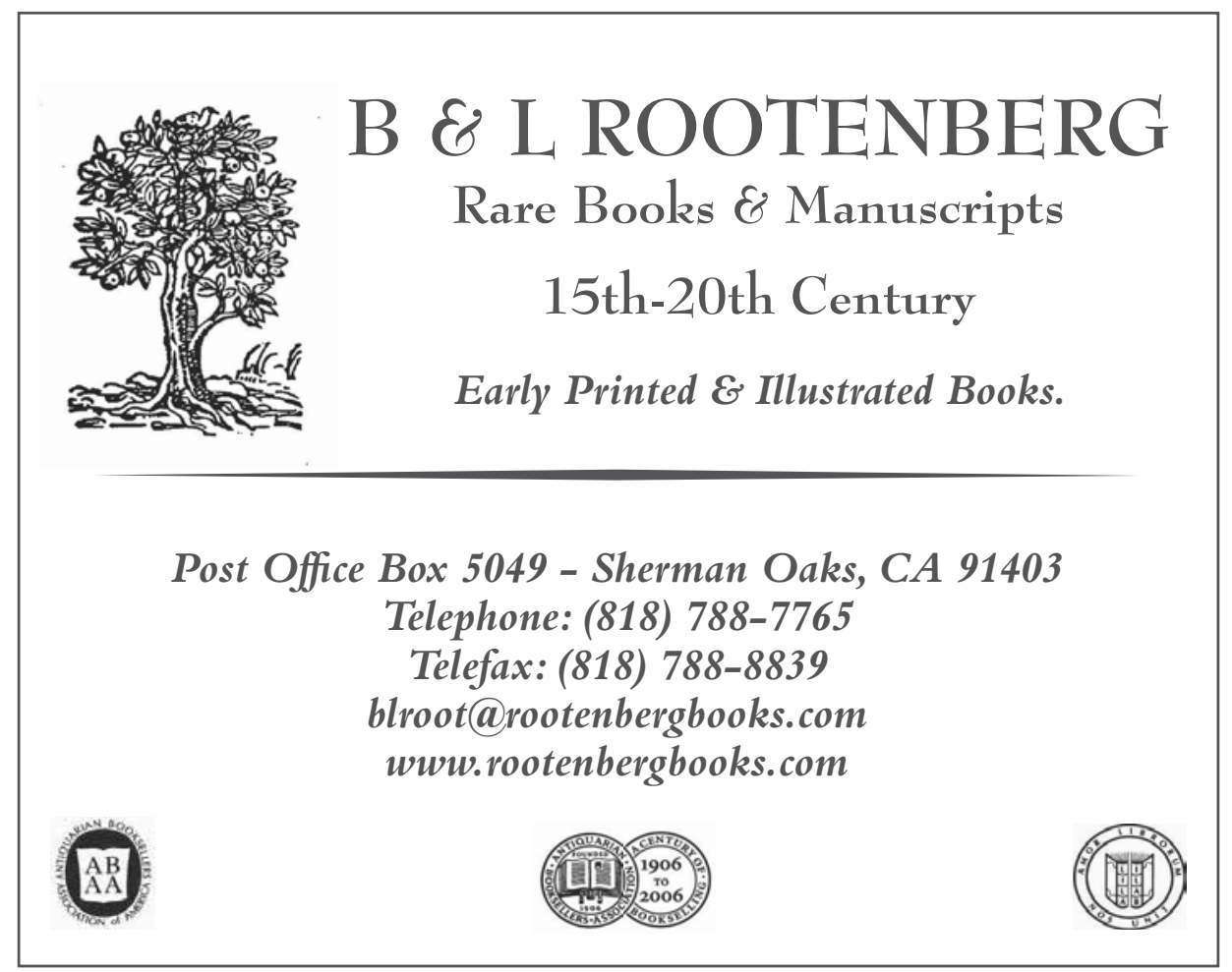


Finally, there are documents of the Revolution concerning the monasteries of Arles and their fate. Tome 3 of the four-volume history of the church in Arles by Véran, (described above) is a history of the church during the Revolution. It includes the names of the religious men and women in an institution, lists the amount of silver confiscated from each house, and identifies its land holdings. Religious persons who wanted to continue to live in common had to remove to private houses and cease wearing the religious habit. There is a description of the fate of the great abbey of St. Caesarius: "the vast monastery of St. Caesarius was sold in 1793 to Julien Juran Macon who divided it among a great number of workers who prepared to demolish it for the exploitation of their portions," presumably to use or sell the stone. ${ }^{22}$ The effect of the grand events of the Revolution on a particular town and its inhabitants is here seen through the eyes of a contemporary man of learning who was obviously much saddened by the destruction he noted around himself.

In addition to the library, brief mention should also be made of the resources for historical information in archives. The archives of the city of Arles are next door to the library, in the same building. Although their collections are mostly post-Revolutionary, they also contain several earlier documents that have mostly to do with land. Document GG-106 concerning the land holdings of the abbey of St. Caesarius also includes a curious letter to the archbishop, signed by ten of its nuns. Complaining that the abbess has lent a considerable sum of money to a stranger, without the usual formalities, the nuns are worried about the finances of the abbey that supports them. The letter is filled with the kind of spelling mistakes made by the less learned, and some of the signatures are in very poor hands, causing one to wonder about the state of the abbey and the education of the nuns in it. Again, the existence of this kind of letter among the documents of the archive would most likely not have been anticipated in advance by a researcher. ${ }^{23}$ There are also documents relating to Arles contained in the regional archives in Marseille (Archives Départementales des Bouches-duRhône), ${ }^{24}$ including an inventory of the liturgical books of the abbey of St. Caesarius. ${ }^{25}$

22. M794, 84 .

23. See Guide des archives communales d'Arles by Françoise Heurley-Chaunier [municipal archivist] (Arles: Archives Communales, Espace Van Gogh, 1989) for a listing of the resources available in the archives.

24. See Guide sommaire et état des fonds des Archives des Bouches-du-Rhône (Marseilles: Archives départementales, 1976) and Les fonds des archives départementales des Bouches-du-Rhône (Archives centrale de Provence) (Marseille: Archives des Bouches-Rhône, 1937). The Web site for the archives is available online at www.archives13.fr/archives13/CG13 (accessed Sept. 2, 2008).

25. See entry no. 89 in Genevois, Genest and Chalandon, Bibliothèques de manuscrits médiévaux en France, 12. 
The comparative ease of working in a smaller collection such as the Médiathèque d'Arles, coupled with the assistance of a librarian well versed in her collec-

tion, was particularly helpful. On the last day of the author's visit, the librarian was working on a newly acquired collection of land documents that had been donated by an important family of Arles. She happened to come across one that concerned a possession of the abbey of St. Caesarius, which she brought to the author's attention because she was aware of the research topic the author was investigating. Such personalized assistance is not usually possible in the larger national libraries. Another fact that can be seen from this summary of the types of documents found in the library in Arles is that even collections in some of the smaller towns in France can contain substantial and interesting documents. While this paper has focused on resources for religious and, in particular, monastic history, there are also many other documents that could be of potential use to the social historian as well, which might not easily be discovered by the use of electronic means.

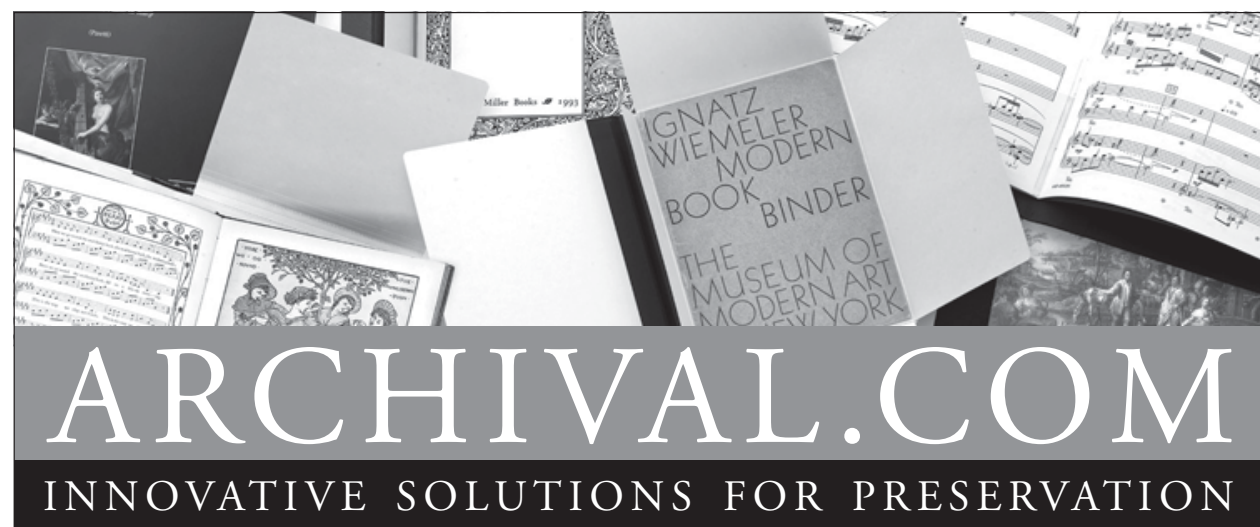

Call for a complete catalog

Pamphlet Binders

Music Binders

Archival Folders

Manuscript Folders

Hinge Board Covers

Academy Folders

Newspaper/Map Folders

Bound Four Flap

Enclosures

Archival Binders
Polypropylene Sheet \& Photo Protectors Archival Boards Adhesives Bookkeeper Century Boxes

Conservation Cloths

Non-Glare Polypropylene Book Covers

CoLibri Book Cover System

\section{ARCHIVAL PRODUCTS}

P.O. Box 1413

Des Moines, Iowa 50306-1413

Phone: 800.526.5640

Fax: 888.220.2397

E-mail: custserv@archival.com Web: archival.com 